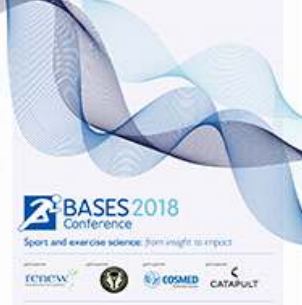

ISSN: 0264-0414 (Print) 1466-447X (Online) Journal homepage: https://www.tandfonline.com/loi/rjsp20

\title{
BASES Conference 2019 - Programme and Abstracts
}

To cite this article: (2019) BASES Conference 2019 - Programme and Abstracts, Journal of Sports Sciences, 37:sup1, 1-93, DOI: 10.1080/02640414.2019.1671688

To link to this article: https://doi.org/10.1080/02640414.2019.1671688

Published online: 08 Nov 2019.

Submit your article to this journal

Џ Article views: 989

Q View related articles 5

View Crossmark data [ᄌ 




2.-BASES 2019

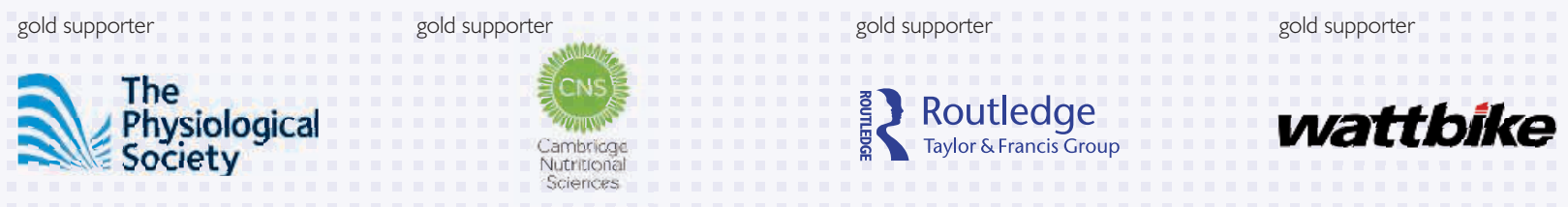




\section{Contents}

Welcome

Prof Richard Tong FBASES - Chair of the British Association of Sport and Exercise Sciences (BASES)

Programme overview

Prof John Saxton FBASES - Chair of the Scientific Programme Committee

Conference programme...

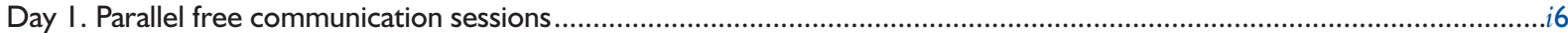

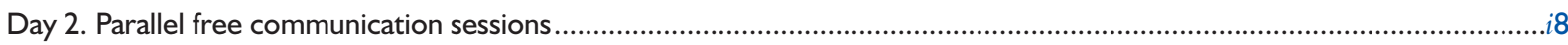

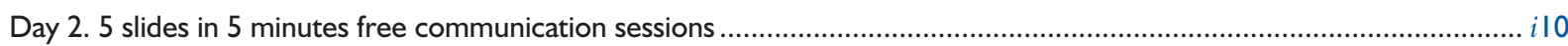

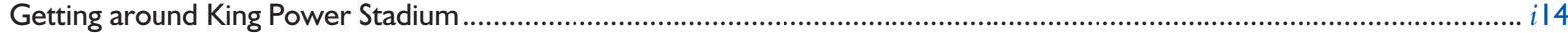

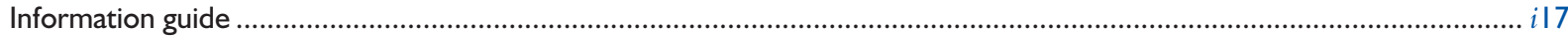

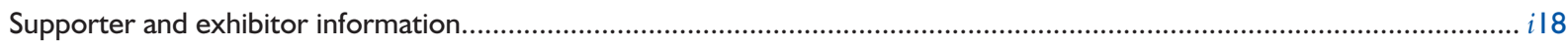

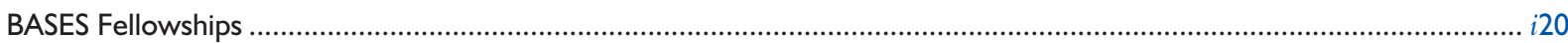

Day I

Special roundtable: Promoting the breadth and impact of sport and exercise sciences research........................................ i22 Prof Mike Tipton, Dr Chris Gaffney, Duncan Brown, Prof Joan Taylor

Invited keynote: Translating science to coaching in performance sport. Prof Carl Foster

Invited symposium: Physical activity and heart health: cardiovascular adaptation and sudden cardiac death Dr David Oxborough and Prof Sanjay Sharma

Invited symposium: Health and mental wellbeing in performance sport: an inter-disciplinary approach

Dr Andy Kirkland, Dr Hayley McEwan and Dr Paul Gorzcynski

Invited symposium: "Lab to field" athlete testing workshop: applications of cycle-based exercise for team sport athletes sponsored by Wattbike Jon Clarke, Mitch Willis and Steve Marshall

Invited symposium: Biomechanics of wheelchair mobility: elite athletes and clinical populations Prof Vicky Tolfrey FBASES and Prof Florentina Hettinga

Invited symposium: "Green exercise": the influence of environment on physical activity, health and wellbeing Prof Keith Davids and Dr Valerie Gladwell

Invited symposium: Wearable technology: friend or foe? .... Dr Grant Abt FBASES and Dr John Toner

Invited symposium: Nutrition, supplement use and prohibited substances in sport: issues, challenges and solutions ...... Irene Riach and Liam Jefferson

Day 2

Invited symposium: Rugby World Cup 2019 special: The role of the sport scientist in player development and preparation for elite team sport competitions.... Dr Martin Roderick, Jon Clarke

Invited symposium: Placebo effects in sport and exercise

Prof Chris Beedie and and Prof Fabrizio Benedetti

Invited symposium: Exercise for osteoporosis - a new expert consensus statement with recommendations.

Dr Katherine Brooke-Wavell and Prof Dawn Skelton

Invited symposium: Exercise and health psychology: innovative intervention strategies to improve health and psychosocial outcomes Prof Catherine Sabiston and Prof Amanda Daley

Invited symposium: Exercise and immune function in elite athletes Prof Neil Walsh and Dr Lettie Bishop

Invited symposium: Biomechanical analysis of walking behaviour and gait patterns: research, impact and implications ......... i36 Dr Brook Galna and Dr Siobhán Strike

Invited symposium: Multidisciplinary team approach to supporting exercisers with relative energy deficiency in sport (RED-S) Dr Nicky Keay and Renee McGregor

Invited keynote: Invited keynote: Shifting the curve of sport and physical activity participation Invited keynote: Shifting the curve of
Prof Mike Weed and and Sarah Ruane

Abstracts 


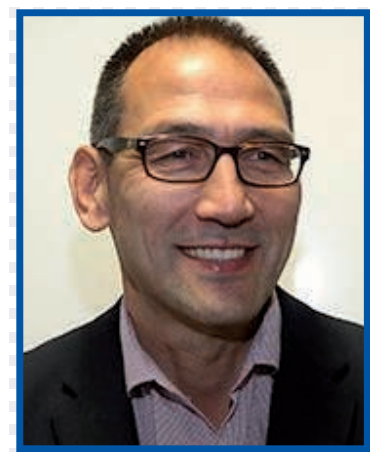

Prof Richard Tong FBASES

Scientific Programme

Committee

- Prof John Saxton FBASES (Chair), Northumbria University

- Dr Stuart Beattie FBASES, Bangor University

- Dr David Broom FBASES, Sheffield Hallam University

- Prof Florentina Hettinga, Northumbria University

- Prof Lars McNaughton FBASES, Edge Hill University

- Prof David Stensel, Loughborough University

- Prof Craig Twist FBASES, University of Chester
Welcome

E)

from Prof Richard Tong FBASES

Chair of the British Association of Sport and Exercise Sciences (BASES)

On behalf of the British Association of Sport and Exercise Sciences, I am pleased to welcome you to BASES Conference 2019. This year's programme promises to be highly stimulating and informative. The keynote speakers, parallel symposia, posters and free communications look set to provide a variety of compelling and inspirational sessions that will undoubtedly live up to the high standard of conference that we are accustomed to. We are delighted to welcome Cambridge Nutritional Sciences, Wattbike, The Physiological Society and Routledge as our official gold supporters.

This year's conference is packed with content and insight, covering an array of topics and presentation formats. The BASES Scientific Programme Committee, chaired by Professor John Saxton FBASES, has secured over 35 expert speakers to deliver keynote lectures and parallel symposia sessions, bringing together a wealth of expertise, experience and passion for sport and exercise science in both research and applied settings. I would like to extend my thanks on behalf of BASES to the Scientific Programme Committee for preparing such an excellent programme.

We extend a special welcome to our invited keynote speakers: Professor Carl Foster from the University of Wisconsin-La Crosse, USA, Professor Mike Weed from Canterbury Christ Church University and Sarah Ruane from Sport England. With combined experience of over 50 years in applied sports science and public health contexts respectively, both opening and closing sessions will undoubtedly be packed with thought-provoking insight, extensive knowledge and topical debate. We also welcome two distinguished overseas speakers as part of this year's programme of parallel symposia: Professor Catherine Sabiston from the University of Toronto, Canada and Professor Fabrizio Benedetti from the University of Turin, Italy.

I would like to extend a sincere thank you to all of our exhibitors. Walkers Hall will house all our supporters and exhibitors, in addition to refreshments and posters, making this a vibrant networking hub to spend your time outside of the scheduled conference sessions. Please take time to visit the exhibition stands and speak to our conference sponsors, who will be showcasing a range of innovative and industry-leading products, services and publications.

Seven prestigious awards will be contested at this year's conference, which seek to reward outstanding contributions to sport and exercise sciences by BASES members. We would like to thank our award sponsors: Cranlea, Human Kinetics, Routledge/Taylor and Francis and Sportesse.

Opportunities for socialising and networking play a key part in this event. To facilitate this, we have scheduled plenty of breaks and extended lunch periods, so please utilise these to talk to your fellow delegates and renew old acquaintances. Following the BASES Annual General Meeting on day one, delegates will have a chance to let their hair down at our annual gala drinks reception and conference dinner, which takes place in the Keith Weller Lounge.

And finally thank you for taking time out of your busy schedule to attend this conference and for being part of BASES signature annual event. I hope you take the time to share your extensive knowledge with other delegates and that your time at the conference is worthwhile and enjoyable. 


\title{
Programme overview
}

\author{
from Prof John Saxton FBASES \\ Chair of the Scientific Programme Committee
}

On behalf of the Scientific Programme Committee, it is my pleasure to welcome you to BASES Conference 2019. After last year's jaunt to the beautiful North Yorkshire town of Harrogate, this year our annual flagship event returns to the Midlands. The King Power Stadium in Leicester is the home of the 2015-16 Premier League Champions, Leicester City Football Club, and encompasses a modern, purpose-built conference venue with superb facilities that will be a fitting backdrop to the UKs premier sport and exercise sciences conference.

The 2019 programme reflects the broad range of interests of BASES members, and includes presentations by world-leading researchers, academics and practitioners from around the globe. I am delighted that the Scientific Programme Committee has secured outstanding opening and closing keynote sessions that you will not want to miss. Professor Carl Foster from the University of Wisconsin-La-Crosse will be drawing upon his vast experience to present the opening conference keynote on translating science to coaching in performance sport. Our closing keynote session will be presented by Professor Mike Weed from Canterbury Christ Church University and Sarah Ruane, National Strategic Lead for Health at Sport England, whose work is at the cutting-edge of physical activity and public health policy. They will be addressing the important question of whether it is possible to shift the curve of sport and physical activity participation at the population level.

The BASES Annual General Meeting (AGM) will be held at the end of the first day. A full attendance at any AGM is always a challenge after a packed day of presentations, but please remember that attending the BASES AGM provides a unique opportunity to comment on a range of issues that not only have an impact on the Association, but also on the standing of sport and exercise sciences in the UK. It is in all our interests to participate in discussions that will shape the future direction of the Association.

The essence of any scientific conference is sharing research findings. This is effectively achieved via free communications and poster presentations. These sessions should be a two-way process, with authors presenting their research findings, followed by constructive exchanges that provide opportunities to discuss, challenge and debate. This not only enhances our knowledge and understanding of phenomena, but also uncovers new and innovative avenues for research. I would therefore encourage you all to support your fellow researchers by attending and participating in the free communication presentations, 5 slides in 5 minutes presentations, and poster viewing sessions that take place across the two days of the conference.

Finally, on behalf of the Scientific Programme Committee, I hope you find the next two days collegial, enjoyable and informative, and that you leave the conference inspired and enthused about your commitment to making a difference within your realm of professional activity.

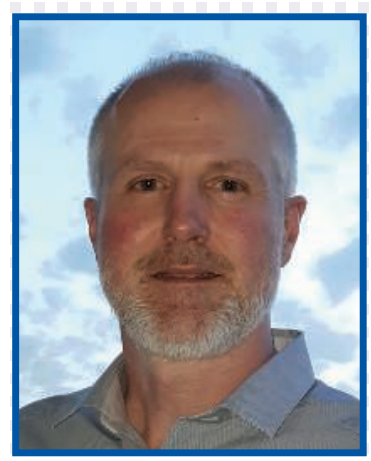

Prof John Saxton FBASES

\section{Abstract Reviewers}

- Dr Anna Myers

- Dr Anthony Papathomas

- Dr Audrey Duncan

- Dr Mike Price FBASES

- Prof Michael Duncan FBASES

- Dr Neil Clarke

- Dr Mathew Hill

- Dr Adam Gledhill FBASES

- Dr Adam Grainger

- Adam Hawkey FBASES

- Dr Doug Thake

- Prof Brendan Cropley FBASES

- Dr Camilla Knight

- Prof Costas Karageorghis FBASES

- Dr David Broom FBASES

- Dr Daniel Bailey

- Dr Denise Hill

- Dr Emma Kavanagh

- Franky Mulloy

- Dr Ibrahim Akubat

- Dr James Hopker

- Dr Kiara Lewis FBASES

- Dr Lindsay Bottoms

- Dr Mark Faghy

- Dr Matthew Pain

- Dr Mustafa Sarkar

- Dr Paul M. Smith

- Richard Taylor

- Prof Richard Thelwell FBASES

- Dr Stuart Beattie FBASES

- Shaun McLaren

- Shane Malone

- Dr Theodoros Bampouras

- Prof Zoe Knowles FBASES

exhibitors




\section{DAY I - TUESDAY I9 NOVEMBER 2019}

08:30

09:00-09:45

$09: 50$

10:00-II:00

$11: 30-12: 30$

$12: 30-14: 00$

14:00-15:30

15:30-16:00

16:00-17:00

17:15-18:00

Registration and refreshments

Special roundtable: Promoting the breadth and impact of sport and exercise sciences research

Prof Mike Tipton, University of Portsmouth, Dr Chris Gaffney, Lancaster University, Duncan Brown, Emsi and Prof Joan Taylor,

De Montford University

Chair: Prof John Saxton FBASES

Sport and exercise science continues to see significant growth in both its application and in student numbers in higher education. However, public understanding of the skills sport and exercise science fosters amongst graduates can often be narrow and outdated. In this roundtable session, presenters will explore the breadth of sport and exercise science and how education programmes can be established and evidenced within institutions.

DI.SI. Legends Lounge

Opening address Welcome from BASES Chair, Prof Richard Tong FBASES

Invited keynote: Translating science to coaching in performance sport

Prof Carl Foster, University of Wisconsin-La Crosse, USA

Chair: Prof Florentina Hettinga

Exercise science has a long tradition of trying to understand the fundamental processes that contribute to human movement; sport science aims to translate those scientific findings to an end user - the coach. In this keynote lecture. Prof Carl Foster will draw upon his extensive experience working in performance environments to discuss how more fundamental knowledge must be distilled to a focused common denominator to help the coach make decisions about the planning and execution of training programmes for athletes.

DI.S2. Keith Weller Lounge

Poster viewing, exhibition and refreshments

Walker's Hal

Parallel invited symposia:

Physical activity and heart health: cardiovascular adaptation and sudden cardiac death

Dr David Oxborough, Liverpool John Moores University and Prof Sanjay Sharma, St George's, University of London

Chair: Prof John Saxton FBASES

Sudden cardiac death is a rare but tragic event that can occur in athletes. This session will cover the multifactorial nature of physiological adaptation in the athlete's heart highlighting the impact of exercise training on structure and function of the cardiac chambers. Causes of sudden cardiac death will be discussed and the differentiation of the "athlete's heart" from pathology will be explored.
Health and mental wellbeing in performance sport: an interdisciplinary approach

Dr Andy Kirkland, University of Stirling, Dr Hayley McEwan, University of West of Scotland and Dr Paul Gorzcynski, University of Portsmouth

Chair: Dr Stuart Beattie FBASES

Research into mental health in performance sport has typically focused on athlete perspectives: however, in this interactive research project, the presenters will seek delegates' perspectives surrounding mental health and wellbeing. A "World Cafe" approach will be used to draw upon and capture diverse experiences and expertise relating to mental health in the working environment.

\section{DI.S3.2. Legends Lounge}

"Lab to field" athlete testing workshop: applications of cycle-based exercise for team sport athletes sponsored by Wattbike

Jon Clarke, England RFU, Mitch Willis, Leicester City FC and Steve Marshall, Wattbike

Chair: Dr Adam Grainger

Practitioners use "off feet" conditioning in an attempt to deliver an alternative training stimulus while reducing mechanical loading. These practices are often employed in-season to enhance or maintain physical qualities and in rehabilitation after injury. Using examples from high-performance sport, this session explores the theoretical and practical application of cycle-based training in the conditioning practices of team athletes.

DI.S3.3. Rowley Suite Walker's Hall

Parallel free communication sessions

Walker's Hal

\section{Parallel invited symposia}

Biomechanics of wheelchair mobility: elite athletes and clinical populations Prof Vicky Tolfrey FBASES, Loughborough University and Prof Florentina Hettinga, Northumbria University Chair: Adam Hawkey FBASES

Gait analysis is a widely used method to assess gait characteristics of clinical populations, however, less is known on the biomechanics of wheelchair mobility. This session will firstly explore performance and biomechanics in elite wheelchair sport, before focusing on wheelchair propulsion in daily life and the wider context of physical activity engagement of special populations.

\section{DI.S5.I. Legends Lounge}

“Green exercise": the influence of environment on physical activity, health and wellbeing

Prof Keith Davids, Sheffield Hallam University and Dr Valerie Gladwell, University of Essex

Chair: Dr Miranda Armstrong Exercising in natural environments provides multiple health benefits, in addition to motivating and facilitating physical activity. In this session, $\mathrm{Dr}$ Valerie Gladwell will examine the physiological and psychological changes that result from interactions between the environment and exercise and the resultant impact on health and wellbeing. Prof Keith Davids will then explore the ecologica dynamics perspective of "green exercise".

\section{DI.S5.2. Rowley Suite} BASES Annual General Meeting

Gala drinks reception / Conference dinner
Wearable technology: friend or foe?

Dr Grant Abt FBASES and Dr ohn Toner, University of Hull Chair: Prof Lars McNaughton FBASES

This session will explore the use of consumer wearable technology for monitoring physical activity. The presenters will draw on their extensive expertise in this area to discuss the validity of devices for measuring physical activity, together with a review of the research examining how users engage with these technologies. Delegates will leave with a greater understanding and appreciation of the opportunities and challenges of working with wearable technology in relation to both research and practice. DI.S5.3. Gallery Suite
Nutrition, supplement use and prohibited substances in sport: issues, challenges and solutions

Irene Riach, sportscotland Institute of Sport and Liam Jefferson, UK Anti-Doping Chair: Dr Mike Price FBASES

There are significant risks for athletes ssociated with the use of sports foods, energy drinks, vitamins and supplements. This roundtable session will bust myths around the use of supplements and highlight the importance of a "food first" approach. Featuring an update on the upcoming changes to the World Anti-Doping Code and Prohibited List in 2020, the session will explore which ADRV's apply to athlete support personne and how practitioners can protect themselves and their athletes.

DI.S5.4. Premier Lounge 2 Rowley Suite Gallery Suite / Keith Weller Lounge 
DAY 2 - WEDNESDAY 20 NOVEMBER 2019

08:15

09:00-09:55

|0.00- I I:00

II:30-12:45

12:45-14:00

$14: 00-14: 55$

\begin{tabular}{|l|l}
\hline Exercise and health \\
psychology: innovative \\
intervention strategies \\
to improve health and \\
psychosocial outcomes \\
Prof Catherine Sabiston, \\
University of Toronto and Prof \\
Amanda Daley, Loughborough \\
University \\
Chair: Prof Zoe Knowles FBASES \\
\hline In this session Prof Catherine \\
Sabiston and Prof Amanda Daley \\
will present evidence about how \\
innovative interventions can be \\
used to encourage the population \\
to participate in increased physical \\
activity to improve psychological \\
and wellbeing outcomes. The \\
first presentation will focus on \\
collaborative research landscapes \\
for implementing physical \\
activity interventions to improve \\
psychosocial wellbeing for individuals \\
with cancer. The second will \\
focus on how the population can \\
be "nudged" into making better \\
decisions about their health and \\
wellbeing, using physical activity \\
calorie equivalent labelling as \\
an exemplar.
\end{tabular}

D2.S4.I.

Registration and drinks

Parallel invited symposia:

Rugby World Cup 2019 special: the role of the sport scientist in playe development and preparation for elite team sport competitions

Dr Martin Roderick, Durham University and Jon Clarke, England RFU

Chair: Prof Craig Twist FBASES

Providing an academic, practitioner and athlete's perspective, this interactive discussion will explore the support processes provided to elite rugby players and the extent to which these offer effective strategies for enhancing practice, performance and health. Practitioners and researchers will gain a deeper understanding of the athlete support process, the role of the sport teams for major competitions.

D2.S2.I. Keith Weller Lounge

Parallel free communication sessions

Parallel $\mathbf{5}$ slides in $\mathbf{5}$ minutes free communication sessions

D2.SI. scientist and the broader impact on those involved in the development and preparation of elite sports

D2.S2.2. Rowley Suite

Placebo effects in sport and exercise Prof Chris Beedie, University of Kent and Prof Fabrizio Benedetti, University of Turin

Chair: Dr Grant Abt FBASES

The need for conceptual clarity, methodological rigour, and the elucidation of neurobiological mechanisms relating to placebo effects in sport and exercise has been highlighted in a recent consensus statement published in the European Journal of Sport and Exercise. In this session, two of the leading authors involved in the statement will share their viewpoints. Prof Chris Beedie will provide an overview of placebo effects in sport and exercise; and Prof Fabrizio Benedetti will expand on the neurobiological mechanisms underlying placebo effects.

Poster viewing, exhibition and refreshments

Walkers Hall

Lunch, poster discussions and exhibition

Walkers Hal

Exercise for osteoporosis - a new expert consensus statement with recommendations

Dr Katherine Brooke-Wavell, Loughborough University and Prof Dawn Skelton, Glasgow Caledonian University

Chair: Dr David Broom FBASES

This session will describe the evidence base for the Strong Steady \& Straight Consensus Statement from the Royal Osteoporosis Society. Dr Katherine Brooke-Wavell and Prof Dawn Skelton will explain the importance of progressive strength training, impact and falls prevention exercise for improving bone strength and reducing falls risk. The importance of exercise in "caring" for the spine will be discussed, including techniques for moving and lifting, and for posture and pain following vertebral fractures.

D2.S2.3. Legends Lounge

15:00-16:00

Keith Weller Lounge

Exercise and immune
function in elite athletes
Prof Neil Walsh, Bangor
University and Dr Lettie
Bishop, Loughborough
University
Chair: Prof David Stensel
This session will focus on exercise,
immune defence and illness; the
good, the bad and the ugly. Prof
Neil Walsh and Dr Lettie Bishop
will demonstrate how past research
has led to current thinking on the
subject and ask the question: do the
changes seen in immune defence
matter clinically? The presentations will
consider whether it is time for a new
paradigm to minimise the impact of
illness on performance and, with this
in mind, explore new perspectives on
nutritional interactions for
athlete health.

Biomechanical analysis of walking behaviour and gait patterns: research, impact and implications

Dr Brook Galna, Newcastle University Clinical Ageing

Research Unit and Dr Siobhán Strike, University of Roehampton

Chair: Adam Hawkey FBASES

This session will explore the research, mpact and applications of analysing walking/running behaviour and gait patterns. Dr Siobhán Strike will explore the challenges of asymmetric movements, as this is particularly relevant in sport (such as turning, dynamic tasks, cutting manoevres), in rehabilitation and in disability sport (transtibial amputations). Dr Brook Galna will then explore the analysis of walking behaviour and gait patterns in persons living with neurogenerative conditions, and will expand on its potential for diagnosis, progression monitoring and interventions.
Multidisciplinary team approach to supporting exercisers with relative energy deficiency in sport (RED-S)

Dr Nicky Keay, Durham University and Renee McGregor, EN:SPIRE Clinic Chair: Prof Lars McNaughton FBASES

Low energy availability due to relative energy deficiency in sport (RED-S) results in adverse clinical outcomes on health and performance affecting a wide range of exercisers. Effective identification and management of individuals at risk of RED-S requires collaboration from members of multidisciplinary teams: medical doctors, clinical dieticians, healthcare professionals and coaches. The presenters will discuss best clinical practice to support exercisers at risk of RED-S, drawing on recent and ongoing research into the condition.

Invited keynote: Shifting the curve of sport and physical activity participation

Prof Mike Weed, Canterbury Christ Church University and Sarah Ruane, Sport England.

Chair: Prof John Saxton FBASES

In this interactive keynote session, Prof Mike Weed will present national survey and intervention data as a means to explore whether participation levels could be saturated, from a comparison of changes in individual participation versus changes in the population curve, prior to addressing the implications for future policy and implementation. Sarah Ruane will then share the latest insight and trends in participation, before considering what must change and what can be built-on to increase participation in the context of what is shaping our society's physical activity behaviours.

D2.S5. Keith Weller Lounge 


\section{Day I. Parallel free communication sessions}

Physical Activity for Health

Dr David Broom FBASES

\begin{tabular}{|c|c|c|}
\hline 14:00 & DI.S4.I(I) & $\begin{array}{l}\text { Associations of total daily sitting time with cardiovascular disease and diabetes incidence: a } \\
\text { systematic review and meta-analysis of prospective studies } \\
\text { Daniel P Bailey, David J Hewson, Rachael B Champion \& Suzan M Sayegh }\end{array}$ \\
\hline 14:15 & DI.S4.I(2) & $\begin{array}{l}\text { Development of a sedentary behaviour workplace intervention for police staff using the } \\
\text { behaviour change wheel } \\
\text { Marsha L Brierley, Angel M Chater, Lindsey R Smith \& Daniel P Bailey }\end{array}$ \\
\hline 14:30 & DI.S4.I(3) & $\begin{array}{l}\text { Using accelerometery to classify physical activity intensity in older adults: what is the } \\
\text { optimal wear-site? } \\
\text { Michael J Duncan, Alex Rowlands, Chelsey Lawson, Sheila Leddington-Wright, Matt Hill, Martyn Morris, Emma } \\
\text { Eyre \& Jason Tallis }\end{array}$ \\
\hline 14:45 & DI.S4.I(4) & $\begin{array}{l}\text { Effectiveness of an 8-week exercise intervention on coping skills, resilience and physical fitness } \\
\text { in drug addicts } \\
\text { Gianpiero Greco, Stefania Cataldi, Piergiorgio Di Terlizzi \& Francesco Fischetti }\end{array}$ \\
\hline 15:00 & DI.S4.I(5) & $\begin{array}{l}\text { The effect of high impact exercise on bone marrow lesions in postmenopausal women } \\
\text { Chris Hartley, Robert Kerslake, Jonathan P Folland \& Katherine Brooke-Wavell }\end{array}$ \\
\hline 15:15 & DI.S4.I(6) & $\begin{array}{l}\text { Compensation for intended diet-induced weight loss: appetite or physical activity? } \\
\text { Anna Myers, Nicola Buckland, Graham Finlayson \& John Blundell }\end{array}$ \\
\hline
\end{tabular}

Physiology and Nutrition

Chair: Prof Craig Williams FBASES

I4:00-I5:30, DI.S4.2 Premier Lounge 2

\begin{tabular}{|l|l|l|l|l|l|l|l}
\hline I4:00 & DI.S4.2(I) & $\begin{array}{l}\text { Post-exercise supplementation of sodium bicarbonate improves acid base balance recovery and } \\
\text { subsequent high-intensity boxing specific performance } \\
\text { Lewis A Gough, Steven Rimmer, Andy Sparks, Lars R McNaughton \& Matthew Higgins }\end{array}$ \\
\hline I4:I5 & DI.S4.2(2) & $\begin{array}{l}\text { The dose-response effect of sodium bicarbonate on cycling to exhaustion performance and } \\
\text { gastrointestinal discomfort } \\
\text { William H Gurton, Lewis A Gough \& Katharine E Reed }\end{array}$ \\
\hline I4:30 & DI.S4.2(3) & $\begin{array}{l}\text { Protein supplementation increases gains in maximal oxygen uptake and impacts skeletal muscle } \\
\text { adaptations during prolonged endurance training } \\
\text { Pim Knuiman, Roland Hangelbroek, Mark Boekschoten, Luc van Loon, Jeroen Wouters, Renger Witkamp, Maria } \\
\text { Hopman5 \& Marco Mensink }\end{array}$ \\
\hline I4:45 & DI.S4.2(4) & $\begin{array}{l}\text { The BASES Expert Statement on Extracellular Buffering Agents } \\
\text { Lars McNaughton, Sanjoy K. Deb, Lewis A. Gough, Matt Higgins, Mike Price, Craig Sale \& Andy Sparks }\end{array}$ \\
\hline I5:00 & DI.S4.2(5) & \begin{tabular}{l} 
Flow resistive face masks worn during high-intensity interval training sessions do not improve \\
5-kilometre running performance \\
Mark A Faghy, JP Mayes, Peter I Brown, James Keenan \& Tom M Maden-Wilkinson \\
\hline I5:I5
\end{tabular} & DI.S4.2(6) & $\begin{array}{l}\text { Hypertension and metabolic syndrome prevalence and contributing factors observed in a } \\
\text { territory police organisation in England } \\
\text { James Yates, Jeffrey Aldous, Andrew Mitchell, Daniel Bailey \& Joanna Richards }\end{array}$ \\
\hline
\end{tabular}

\section{4:00-I5:30, DI.S4.3. Legends Lounge}

\begin{tabular}{|l|l|l|l|l|l|l|l|}
\hline I4:00 & DI.S4.3(I) & $\begin{array}{l}\text { How does anyone know when they're really ready? Understanding competitive athletes' } \\
\text { perceptions of psychosocial readiness to return to sport } \\
\text { Adam Gledhill, Andrew Manley \& Matthew Allanson }\end{array}$ \\
\hline $\mathbf{I 4 : I 5}$ & DI.S4.3(2) & $\begin{array}{l}\text { The BASES Expert Statement on Mental Health Literacy in Elite Sport } \\
\text { Paul Gorczynski, Kass Gibson, Richard Thelwell, Anthony Papathomas, Chris Harwood \& Florence Kinnafick }\end{array}$ \\
\hline $\mathbf{I 4 : 3 0}$ & DI.S4.3(3) & $\begin{array}{l}\text { Exploration of psychological resilience during a 25-day endurance challenge in an extreme } \\
\text { environment } \\
\text { David W Harrison, Mustafa Sarkar, Chris Saward \& Caroline Sunderland }\end{array}$ \\
\hline $\mathbf{I 4 : 4 5}$ & DI.S4.3(4) & $\begin{array}{l}\text { When it HIITs you, you feel no pain: psychological effects of respite-active music in HIIT } \\
\text { Costas I. Karageorghis, Leighton Jones, Luke W. Howard, Rhys M. Thomas, Panayiotis Moulashis \& Sam J. } \\
\text { Santich }\end{array}$ \\
\hline
\end{tabular}




\begin{tabular}{|c|c|c|}
\hline 15:00 & DI.S4.3(5) & $\begin{array}{l}\text { The BASES Expert Statement on Burnout in Sport } \\
\text { Daniel Madigan, Henrik Gustafsson, Alan L. Smith, Thomas D. Raedeke \& Andrew P. Hill }\end{array}$ \\
\hline 15:15 & DI.S4.3(6) & $\begin{array}{l}\text { Exercise addiction prevalence and correlates in the absence of eating disorder symptomology. } \\
\text { A systematic review and meta-analysis } \\
\text { Mike Trott, Sarah Jackson, Joseph Firth,4,5, Abigail Fisher, James Johnstone, Amit Mistry, Brendon Stubbs } \\
\text { \& Lee Smith }\end{array}$ \\
\hline
\end{tabular}

\section{Sport and Performance (Session I)}

Chair: Prof Craig Twist FBASES

\begin{tabular}{|c|c|c|}
\hline 14:00 & DI.S4.4(I) & $\begin{array}{l}\text { Do practical cooling manoeuvres utilised during a soccer-specific warm-up and at half time } \\
\text { improve simulated soccer performance at } \mathbf{2 8}^{\circ} \mathbf{C} \text { WBGT? } \\
\text { Jeffrey W. Aldous, Peter McDonald, Liam P. Sweeney, Nicole Raffermati, Joanna Richards, John Hough } \\
\text { \& Christopher Tyler }\end{array}$ \\
\hline 14:15 & DI.S4.4(2) & $\begin{array}{l}\text { Rugby-specific static activities: are they actually high-intensity? } \\
\text { Eddie J Bradley, Elisabeth Board, Will Evans \& David Archer }\end{array}$ \\
\hline 14:30 & DI.S4.4(3) & $\begin{array}{l}\text { An exploratory case study examining the training loads and effects of mixed martial arts } \\
\text { competition preparation } \\
\text { Christopher Kirk, Dave Clark, Carl Langan-Evans \& James Morton }\end{array}$ \\
\hline 14:45 & DI.S4.4(4) & $\begin{array}{l}\text { Repeated-sprint training in soccer: should we use straight-line and shuttle sprints } \\
\text { interchangeably? } \\
\text { Jonathan M Taylor, Shaun J McLaren, Tom W Macpherson, lain R Spears \& Matthew Weston }\end{array}$ \\
\hline 15:00 & DI.S4.4(5) & $\begin{array}{l}\text { A comparison of a sports-specific, foot-mounted inertial measurement system and three } \\
\text { commercial Global Positioning Systems to quantify soccer-specific movement patterns } \\
\text { Mark Waldron, \& Jamie Harding }\end{array}$ \\
\hline | 5:15 & DI.S4.4(6) & $\begin{array}{l}\text { A comparison of match demands for professional soccer players versus elite youth soccer } \\
\text { players using ball-in-play } \\
\text { Joshua D Wass }\end{array}$ \\
\hline
\end{tabular}

\begin{tabular}{|c|c|c|}
\hline 14:00 & DI.S4.5(I) & $\begin{array}{l}\text { Incidence and prevalence of lumbar stress fracture in English County Cricket fast bowlers, } \\
\text { association with bowling workload and seasonal variation } \\
\text { Peter Alway, Katherine Brooke-Wavell, Ben Langley, Mark King \& Nicholas Peirce }\end{array}$ \\
\hline 14:15 & DI.S4.5(2) & $\begin{array}{l}\text { The minimum effective training dose required to increase IRM strength in resistance-trained } \\
\text { men: a systematic review } \\
\text { Patroklos Androulakis-Korakakis, James P Fisher \& James Steele }\end{array}$ \\
\hline 14:30 & DI.S4.5(3) & $\begin{array}{l}\text { The influence of cornering on track cycling aerodynamics } \\
\text { Shaun Fitzgerald, Richard M Kelso, Paul N Grimshaw \& Andrew Warr }\end{array}$ \\
\hline 14:45 & DI.S4.5(4) & $\begin{array}{l}\text { The effects of age and body fat content on post downhill run recovery following whole body } \\
\text { cryotherapy } \\
\text { Adnan Haq, William J Ribbans, \& Anthony W Baross }\end{array}$ \\
\hline 15:00 & DI.S4.5(5) & $\begin{array}{l}\text { A meta-analysis of the acute effect of strength training on speed running performance } \\
\text { José F Barquero Jiménez \& Walter Salazar Rojas }\end{array}$ \\
\hline 15:15 & DI.S4.5(6) & $\begin{array}{l}\text { The relationship between integrated external:internal load ratios and next-day subjective } \\
\text { wellbeing in academy rugby union players } \\
\text { Richard Taylor, Tony Myers \& Ibraham Akubat }\end{array}$ \\
\hline
\end{tabular}




\section{Day 2. Parallel free communication sessions}

Biomechanics and Motor Behaviour

Chair: Prof Florentina Hettinga FBASES

\begin{tabular}{|c|c|c|}
\hline I I:30 & D2.S3.I(I) & $\begin{array}{l}\text { A kinetic and kinematic analysis of the rear foot elevated split squat five repetition maximum } \\
\text { Mark Helme, Stacey Emmonds \& Chris Low }\end{array}$ \\
\hline | I:45 & D2.S3.I(2) & $\begin{array}{l}\text { Investigation of running-related injury prevalence and trends in short, middle and long- } \\
\text { distance recreational runners } \\
\text { Anna Kosciuk, Nicola Swann \& Hannah Moir }\end{array}$ \\
\hline 12:00 & D2.S3.I(3) & $\begin{array}{l}\text { Neuromechanics of different resistance training contractions in older adults } \\
\text { Emmet McDermott, Thomas Balshaw,. Katherine Brooke-Wavell,, Thomas Maden-Wilkinson \& } \\
\text { Jonathan Folland, }\end{array}$ \\
\hline $12: 15$ & D2.S3.I(4) & $\begin{array}{l}\text { The effect of neuromuscular training combined with electroacupuncture on the knee joint } \\
\text { stiffness characteristics in young recreational athletes } \\
\text { Dan Wang, Peng Yuan, Yilin Xu, Yunchuan Wu, Weiwei Yang, Daniel Fong \& Eamonn Delahunt }\end{array}$ \\
\hline $12: 30$ & D2.S3.I(5) & $\begin{array}{l}\text { Static posture and competition level do not predict dynamic pelvic posture in } \\
\text { equestrian riders } \\
\text { Celeste A Wilkins, Kathryn J Nankervis, Laurence Protheroe \& Stephen B Draper }\end{array}$ \\
\hline
\end{tabular}

Physical Activity for Health

Chair: Dr Daniel Bailey

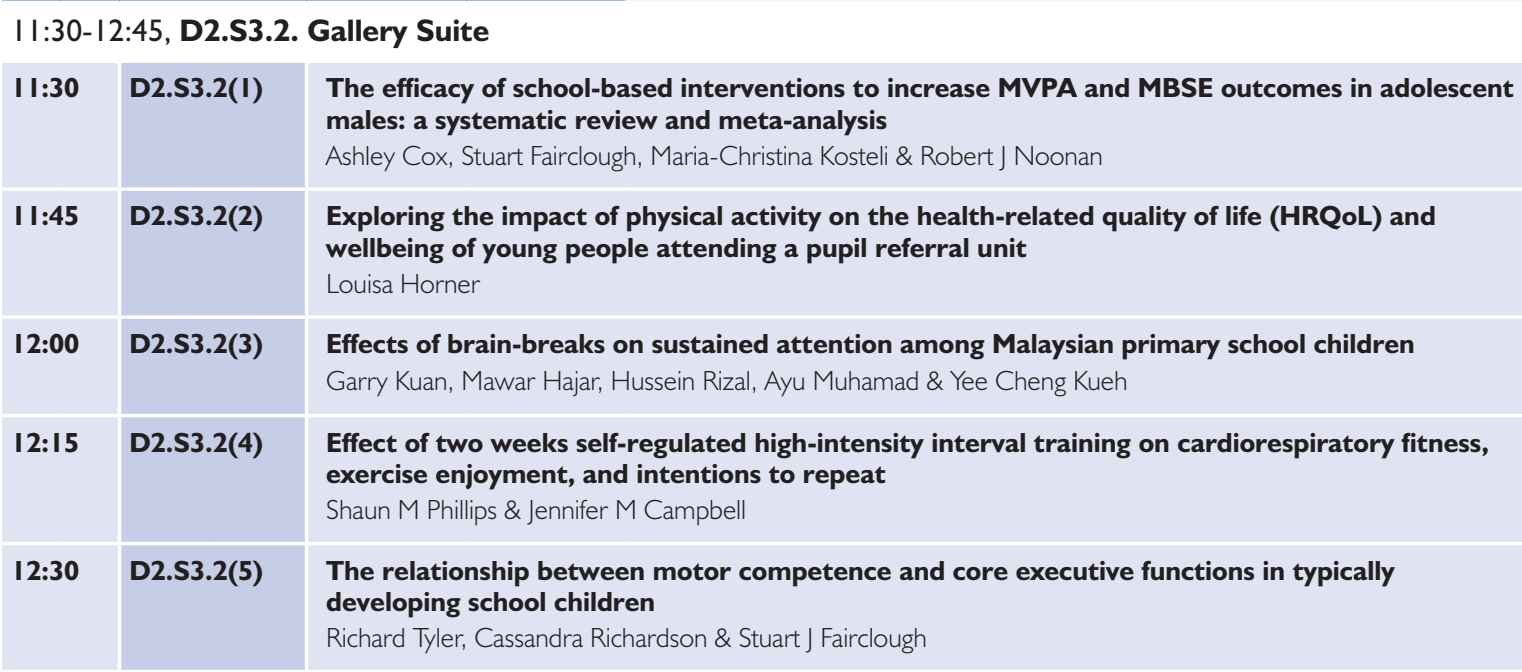

\begin{tabular}{|l|l|l|l|l|l|l|l|}
\hline I I:30- & 2:45, D2.S3.3 & Legends Lounge \\
\hline I I:30 & D2.S3.3(I) & $\begin{array}{l}\text { An interdisciplinary approach to athlete selection: a case study of W-Series } \\
\text { Brian Cameron, Kotryna K. Fraser, Norbert Filippits, Marisa Dawes, Lara Carlson \& Tony Turner }\end{array}$ \\
\hline I I:45 & D2.S3.3(2) & $\begin{array}{l}\text { The BASES Expert Statement on Reflective Practice: the Key to Experiential Learning } \\
\text { Emma Huntley, Brendan Cropley, Zoe Knowles \& Andy Miles }\end{array}$ \\
\hline I2:00 & D2.S3.3(3) & $\begin{array}{l}\text { Coach learning and practice in endurance sport: why context matters to sports scientists } \\
\text { Andrew Kirkland }\end{array}$ \\
\hline I2:15 & D2.S3.3(4) & $\begin{array}{l}\text { Perceptions of the talent development environment across English academy football: } \\
\text { a level analysis } \\
\text { Tom Mitchell, Adam Gledhill \& Kevin Till }\end{array}$ \\
\hline I2:30 & D2.S3.3(5) & $\begin{array}{l}\text { An ecologically informed approach to applied sport psychology practice within an elite youth } \\
\text { football academy } \\
\text { Lewis Charnock, Martin Littlewood, Rob Morris \& Mark Nesti }\end{array}$ \\
\hline
\end{tabular}




\begin{tabular}{|l|l|l|l|l|l|l|l|}
\hline I I:30- I 2:45, D2.S3.4 Rowley Suite \\
\hline I I:30 & D2.S3.4(I) & $\begin{array}{l}\text { Effects of personality on decision accuracy of football field referees and VARs } \\
\text { Andreas Graefe, Alexander Bauer \& Guido Ellert }\end{array}$ \\
\hline I I:45 & D2.S3.4(2) & $\begin{array}{l}\text { An evaluation of UK Athletics' clean sport intervention in preventing doping in junior } \\
\text { elite athletes } \\
\text { Philip Hurst, Christoper Ring \& Maria Kavussanu }\end{array}$ \\
\hline I 2:00 & D2.S3.4(3) & $\begin{array}{l}\text { The influence of rational and irrational language on psycho-physiological indices of challenge } \\
\text { and threat appraisal states in varsity netballers } \\
\text { Callum A O'Malley, \& Andrew L Evans }\end{array}$ \\
\hline I 2:I5 & D2.S3.4(4) & $\begin{array}{l}\text { Effect of eye dominance on coincidence anticipation in professional rugby players and } \\
\text { non-athletes } \\
\text { Zoe L Wimshurst \& Greg Neil }\end{array}$ \\
\hline I 2:30 & D2.S3.4(5) & $\begin{array}{l}\text { Performance strategies' moderation of the interaction between adaptive and maladaptive } \\
\text { narcissism on athlete training } \\
\text { Shuge Zhang, Ross Roberts, Amanda Pitkethly \& Cedric English }\end{array}$ \\
\hline
\end{tabular}

Sport and Performance

Chair: Prof Andrew Edwards FBASES

I I:30-12:45, D2.S3.5 Keith Weller Lounge

\begin{tabular}{|l|l|l|}
\hline I I:30 & D2.S3.5(I) & $\begin{array}{l}\text { The anthropometric and performance characteristics of starters and non-starters in elite } \\
\text { Gaelic Football } \\
\text { Kieran Collins \& Barry Horgan }\end{array}$ \\
\hline $\mathbf{I I : 4 5}$ & D2.S3.5(2) & $\begin{array}{l}\text { The association of relative age and physical profile with players awarded professional contracts } \\
\text { in an elite Scottish soccer academy } \\
\text { Thomas P. Craig \& Paul A. Swinton }\end{array}$ \\
\hline I 2:00 & D2.S3.5(3) & $\begin{array}{l}\text { A comparison of anthropometric and performance profiles between elite and sub-elite hurlers } \\
\text { John Keane, Kieran Collins, Damien Young \& Giuseppe Coratella }\end{array}$ \\
\hline I 2:I5 & D2.S3.5(4) & $\begin{array}{l}\text { Profiling rugby sevens: physical and perceptual responses to travel and performance } \\
\text { Fraser Menzies, Derrick Speirs, Andy Boyd \& Anthony Turner }\end{array}$ \\
\hline I 2:30 & D2.S3.5(5) & $\begin{array}{l}\text { Effects of training and competition on the sleep of elite athletes: a systematic review and } \\
\text { meta-analysis } \\
\text { Spencer S Roberts, Wei-Peng Teo, \& Stuart Warmington }\end{array}$ \\
\hline
\end{tabular}




\section{Day 2. 5 slides in 5 minutes free communication sessions}

Physical Activity for Health

09:00-09:55, D2.SI.I. Gallery Suite
Chair: Dr Kiara Lewis FBASES

\begin{tabular}{|c|c|c|}
\hline 09:00 & D2.SI.I(I) & $\begin{array}{l}\text { Effect of robotic-assisted gait training on arterial stiffness in chronic stroke } \\
\text { James Faulkner, Keeron Stone, Simon Fryer, Amy Wright, Lee Stoner, Louis Martinelli, Helen Hobbs } \\
\text { \& Danielle Lambrick }\end{array}$ \\
\hline 09:08 & D2.SI.I(2) & $\begin{array}{l}\text { Determinants of physical activity are stronger predictors of health-related quality of life in } \\
\text { women with polycystic ovary syndrome than physical activity behaviours } \\
\text { Chris Kite, lan Lahart, loannis Kyrou, Harpal Randeva \& James Brown }\end{array}$ \\
\hline 09:16 & D2.SI.I(3) & $\begin{array}{l}\text { Physical activity in physical education and school recess: different sides of the same coin? } \\
\text { Luis M Moral-Moreno }\end{array}$ \\
\hline 09:24 & D2.SI.I(4) & $\begin{array}{l}\text { WheelNess - reducing health inequalities in Inverness by widening access to cycling } \\
\text { Donna Nicholas \& Emily Ryder }\end{array}$ \\
\hline 09:32 & D2.SI.I(5) & $\begin{array}{l}\text { Accelerometer based physical activity levels differ between week and weekend days in British } \\
\text { preschool children } \\
\text { Clare M Roscoe, Rob S James \& Michael J Duncan }\end{array}$ \\
\hline 09:40 & D2.SI.I(6) & $\begin{array}{l}\text { Association between central adiposity and muscle strength in adult women attending an } \\
\text { activity program in Bogota, Colombia } \\
\text { Oscar F Rubiano, Isabel A Sanchez, Edgar R Acosta, Cristian E Carrilo, Edwin A Valencia, Jaime O Rodriguez, } \\
\text { Juan P Vargas, Cristian Ávila, Samuel jiménez, Natalia S Morales, Luis A Garcia, Manuel A Riveros, Pedro Galvis, } \\
\text { Leidy L Moreno, Carolina Garcia, Daniela Barragán, Juan C Pico, Cristian J Ramírez \& Paula Zamora }\end{array}$ \\
\hline 09:48 & D2.SI.I(7) & $\begin{array}{l}\text { Exploring the facilitators and barriers to establishing regular physical activity through exercise } \\
\text { referral: a qualitative study } \\
\text { Alyx Taylor, Phill Heritage, Jack Humphrey \& Kate Rogers }\end{array}$ \\
\hline
\end{tabular}

Physiology and Nutrition

Chair: Dr Mike Price FBASES

09:00-09:55, D2.S1.2. Premier Lounge 2

\begin{tabular}{|c|c|c|}
\hline 09:00 & D2.SI.2(I) & $\begin{array}{l}\text { Thermoregulatory demands of epée fencing performance during competition } \\
\text { Luke Oates, lan Campbell, Michael Price \& Lindsay Bottoms }\end{array}$ \\
\hline 09:08 & D2.SI.2(2) & $\begin{array}{l}\text { Co-creation of a soccer-specific nutrition education curriculum grounded in the capability, } \\
\text { opportunity, motivation and behaviour change wheel theory } \\
\text { Daniel Carney, Martin Littlewood, Graeme Close \& Rebecca Murphy }\end{array}$ \\
\hline $09: 16$ & D2.S1.2(3) & $\begin{array}{l}\text { The relationship between lumbar spine bone mineral and age in adolescent cricket fast bowlers } \\
\text { Laura Keylock, Katherine Brooke-Wavell, Peter Alway, Nicholas Peirce \& Mark King }\end{array}$ \\
\hline 09:24 & D2.SI.2(4) & $\begin{array}{l}\text { The acute impact of breakfast consumption and omission on postprandial metabolic responses } \\
\text { during rest and exercise in adolescent girls } \\
\text { Victoria Morari, Louise Croft, Daniel P Bailey, Rebecca L Jones \& Julia K Zakrzewski-Fruer }\end{array}$ \\
\hline 09:32 & D2.SI.2(5) & $\begin{array}{l}\text { Peak oxygen consumption of highly trained cyclists: is there a difference between lab and } \\
\text { field testing? } \\
\text { Phillip Smith \& Nicolas Berger }\end{array}$ \\
\hline 09:40 & D2.SI.2(6) & $\begin{array}{l}\text { Delayed carbohydrate feeding during endurance exercise maintains the high fat oxidation rates } \\
\text { observed with training under conditions of low carbohydrate availability } \\
\text { Tim Podlogar, Bonnie Free \& Gareth A Wallis }\end{array}$ \\
\hline 09:48 & D2.S1.2(7) & $\begin{array}{l}\text { Determination of muscle hypertrophy using surface anthropometry during short-term } \\
\text { resistance training in untrained participants } \\
\text { Helen J Ryan-Stewart, James Faulkner, Eloise Paine, Edward Tasker \& Simon Jobson }\end{array}$ \\
\hline
\end{tabular}

\begin{tabular}{|l|l|l|}
\hline $\mathbf{0 9 : 0 0}$ & D2.SI.3(I) & $\begin{array}{l}\text { Supporting conversations about the menstrual cycle } \\
\text { Natalie Brown, Camilla Knight, \& Laura Forrest }\end{array}$ \\
\hline $\mathbf{0 9 : 0 8}$ & D2.SI.3(2) & $\begin{array}{l}\text { Motivation of Special Olympics volunteers: what keeps them coming back? } \\
\text { Liz Carlin \& David Hassan }\end{array}$ \\
\hline
\end{tabular}




\begin{tabular}{|l|l|l|}
\hline 09:I6 & D2.SI.3(3) & $\begin{array}{l}\text { Coaching through principles of play: a conceptualisation of coaches' process of } \\
\text { knowledge generation } \\
\text { Renzo Kerr Cumbo }\end{array}$ \\
\hline $\mathbf{0 9 : 2 4}$ & D2.SI.3(4) & $\begin{array}{l}\text { Relationship between perceived availability of social support, re-injury anxiety in return to sport } \\
\text { and psychological readiness to return to sport in competitive cheerleaders } \\
\text { Megan Lambert \& Adam Gledhill }\end{array}$ \\
\hline $\mathbf{0 9 : 3 2}$ & D2.SI.3(5) & $\begin{array}{l}\text { Effects of virtual reality imagery modelling on novice taekwondo athletes' imagery abilities and } \\
\text { anxiety level } \\
\text { Garry Kuan, Yee-Cheng Kueh \& Nur Haida Ariffin }\end{array}$ \\
\hline $\mathbf{0 9 : 4 0}$ & D2.SI.3(6) & $\begin{array}{l}\text { Influence of a novel mental fatigue protocol on mental fatigue and psychophysiological and } \\
\text { performance responses to a } 3 \text { km time-trial in trained runners } \\
\text { Shaun M Phillips, Rachel Webb \& Hugh Richards }\end{array}$ \\
\hline $\mathbf{0 9 : 4 8}$ & D2.SI.3(7) & $\begin{array}{l}\text { Mindful sport performance enhancement in action: a case study with an elite category one } \\
\text { football academy } \\
\text { Amy L Spencer, Keith A Kaufman, Carol R Glass, Tim R Pineau, Stewart T Cotterill \& Tim Holder }\end{array}$ \\
\hline
\end{tabular}

\section{Sport and Performance (Session I)}

\section{Chris Barnes FBASES}

\begin{tabular}{|l|l|l|l|l|l|l|l}
\hline 09:00-09:55, D2.S I.4. & Rowley Suite \\
\hline $\mathbf{0 9 : 0 0}$ & D2.SI.4(I) & $\begin{array}{l}\text { Seasonal changes in glenohumeral joint isokinetic strength in professional } \\
\text { rugby league players } \\
\text { Matthew Haines, Michael Fish \& David O'Sullivan }\end{array}$ \\
\hline $\mathbf{0 9 : 0 8}$ & D2.SI.4(2) & $\begin{array}{l}\text { The reliability of a battery of fitness assessments when performed around habitual in-season } \\
\text { training in youth elite soccer players } \\
\text { Kevin J Enright, James Morton, John lga, Daniel Lothian, Simon Roberts \& Barry Drust }\end{array}$ \\
\hline $\mathbf{0 9 : 1 6}$ & D2.SI.4(3) & $\begin{array}{l}\text { Competitive engineering for enjoyment in age-grade rugby } \\
\text { Ben Jones, John Mills \& Gavin Sandercock }\end{array}$ \\
\hline $\mathbf{0 9 : 2 4}$ & D2.SI.4(4) & $\begin{array}{l}\text { Performance related feedback in elite English soccer } \\
\text { Tom Page, Barry Drust, Zoe R Knowles, Matt Green \& Matthew Andrew }\end{array}$ \\
\hline $\mathbf{0 9 : 3 2}$ & D2.SI.4(5) & $\begin{array}{l}\text { Comparison of wearable GPS devices for workload monitoring across different weather } \\
\text { conditions and time slots } \\
\text { Shobhit Raizaday, \& Nairn Scobie }\end{array}$ \\
\hline $\mathbf{0 9 : 4 0}$ & D2.SI.4(6) & $\begin{array}{l}\text { Changes in eccentric hamstring strength following competitive soccer match play } \\
\text { Owain Rowat \& Damian Harper }\end{array}$ \\
\hline $\mathbf{0 9 : 4 8}$ & D2.SI.4(7) & $\begin{array}{l}\text { Physical fitness characteristics during a selection event for a female racing driver series } \\
\text { Anthony Turner, Marisa Dawes, Lara Carlson \& Peter McKnight }\end{array}$ \\
\hline
\end{tabular}

\section{Sport and Performance (Session 2)}

\section{Chair: Dr Adam Grainger}

09:00-09:55, D2.S1.5. Keith Weller Lounge

\begin{tabular}{|l|l|l|}
\hline $\mathbf{0 9 : 0 0}$ & D2.SI.5(I) & $\begin{array}{l}\text { Does bio-banding influence physical performance profile in youth basketball? } \\
\text { Jorge Arede, Sean Cumming \& Nuno Leite }\end{array}$ \\
\hline $\mathbf{0 9 : 0 8}$ & D2.SI.5(2) & $\begin{array}{l}\text { Workload assessment and time-loss incidence in elite rugby union players } \\
\text { Ben Cousins, John Morris, Caroline Sunderland, Anthony Bennett, Golnaz Shahtahmasseb \& Simon Cooper }\end{array}$ \\
\hline $\mathbf{0 9 : 1 6}$ & D2.SI.5(3) & $\begin{array}{l}\text { The association between contact injuries and training load indices in elite soccer players } \\
\text { Caoimhe Tiernan, Mark Lyons, Tom Comyns, Alan Nevill \& Giles Warrington }\end{array}$ \\
\hline $\mathbf{0 9 : 2 4}$ & D2.SI.5(4) & $\begin{array}{l}\text { Predictive models for isokinetic ankle muscle strength relating to age, mass, stature, sex } \\
\text { and shoe size } \\
\text { Michael Fish, Matthew Haines, James Milligan \& Jenny Killey }\end{array}$ \\
\hline $\mathbf{0 9 : 3 2}$ & D2.SI.5(5) & $\begin{array}{l}\text { Vertical and horizontal ground reaction force post-activation potentiation following flywheel } \\
\text { eccentric overload half squat exercise } \\
\text { Stuart McErlain-Naylor \& Marco Beato }\end{array}$ \\
\hline $\mathbf{0 9 : 4 0}$ & D2.SI.5(6) & $\begin{array}{l}\text { Lifting straps do not affect mean velocity during deadlifts performed with submaximal loads } \\
\text { Dan Omcirk, Jan Malecek, Ivan Jukic \& James Joseph Tufano }\end{array}$ \\
\hline $\mathbf{0 9 : 4 8}$ & D2.SI.5(7) & $\begin{array}{l}\text { The relationship between handgrip strength and upper body pushing and pulling performance in } \\
\text { Brazilian Jiu-Jitsu athletes } \\
\text { Shaher Shalfawi }\end{array}$ \\
\hline
\end{tabular}


systematically identified and selected. The resulting multicomponent sedentary behaviour intervention is tailored to police staff and ready for pragmatic delivery in their workplace. Explicit use of behaviour change theory in multi-component intervention design will allow for researchers to better assess the relative effectiveness of component BCTs and improve evidence-based practice.

\section{D1.S4.1(3). Using accelerometery to classify} physical activity intensity in older adults: what is the optimal wear-site?

\section{MICHAEL DUNCAN ${ }^{1 *}$, ALEX ROWLANDS $^{2}$, CHELSEY $^{*}$ LAWSON $^{1}$, SHEILA LEDDINGTON-WRIGHT ${ }^{1}$, MATT HILL $^{1}$, MARTYN MORRIS ${ }^{1}$, EMMA EYRE ${ }^{1} \&$ JASON TALLIS $^{1}$

\author{
${ }^{1}$ Coventry University, ${ }^{2}$ University of Leicester \\ *Corresponding author: aa8396@coventry.ac.uk \\ @MikeDunky
}

In the context of an ageing society accelerometry is particularly appropriate to assess physical activity (PA) and sedentary behaviour (SB) in older adults as accelerometry requires no user input during monitoring resulting in greater wearer compliance in older adults, as compared to younger age groups (Doherty et al., 2017, PLOS ONE, 12, e0169649.). Although accelerometry is becoming more common in assessing PA and SB in older adults (Wullems et al., 2017, PLOS ONE, 12, e0188215), few studies have calibrated accelerometer cutpoints with an older adult population and the predominant approach has been to apply cutpoints calibrated in younger adults (Falck et al., 2016, British Journal of Sports Medicine, 51, 800-811). This study aimed to address this issue by determining the optimal accelerometer wear-site specific cut-points for discrimination of SB, light PA and moderate-to-vigorous PA (MVPA) in older adults. Twenty-three adults (14 females) aged 55 to 77 years wore a GENEActiv accelerometer (Activinsights, Cambridge, UK) on their non-dominant wrist, dominant wrist, waist and dominant ankle whilst undertaking eight, five-minute bouts of activity: lay supine, seated reading, slow walking, medium walking, fast walking, folding laundry, sweeping and stationary cycling. $\mathrm{VO}_{2}$ was assessed concurrently using indirect calorimetry (Cortex Metalyser, Cortex, Leipzig, Germany). Receiver-operating-characteristic (ROC) analyses were used to derive wear-site specific cut-points for classifying intensity. Being lay supine and seated reading were classified as sedentary ( $<1.5$ METs), laundry as light (1.512.99 METs) and sweeping, slow, medium and fast walking and cycling all classified as moderate intensity ( $>3$ METs). Areas under ROC curves (AUC) indicated that classification of sedentary activity was good for the non-dominant wrist and excellent for all other wear sites. Classification of moderate-to-vigorous physical activity (MVPA) was excellent (AUC $\geq 0.90$ ) for the waist and ankle, good (AUC $=0.80-0.89)$ for the waist and poor (AUC < 0.70) for the dominant and non-dominant wrists. Overall, the ankle location performed better than other locations. This study presents novel data quantifying energy expenditure in different tasks indicative of daily living and calibrating the GENEActiv accelerometer during these activities when worn at different body locations. The results of the current study suggest that GENEActiv accelerometers demonstrated acceptable criterion validity to assess SB and MVPA. Ankle worn accelerometry appears to provide the most suitable wear location to quantify MVPA and waist worn accelerometry provides the most suitable wear location to quantify SB, in apparently healthy older adults.

\section{D1.S4.1(4). Effectiveness of an 8-week exercise intervention on coping skills, resilience and physical fitness in drug addicts}

\section{GIANPIERO GRECO*, STEFANIA CATALDI, PIERGIORGIO DI TERLIZZI \& FRANCESCO FISCHETTI}

University of Study of Bari, Italy

*Corresponding author: gianpiero.greco@uniba.it @giagre76

Drug addiction may cause health problems and social exclusion (Neale, 2006, In R. Hughes (Ed.), Drugs, policy and politics (pp. 201-226). Maidenhead: McGraw-Hill/Open University Press). Although studies indicate that physical activity levels are inversely related to substance use disorders, it is not clear the role of exercise during drug abuse treatment (Weinstock, Barry, \& Petry, 2008, Addictive Behaviors, 33, 1072-1075). Therefore, the purpose of this study was to investigate the effects of 8-week exercise intervention, as an adjunct to treatment for drug dependent patients (cannabis, opiates, amphetamines, cocaine and heroin addicted), on psychological and physical fitness variables. With institutional ethics approval, 34 male participants (mean age: $45.2 \pm 12.6$ years; stature: $1.77 \pm 0.06 \mathrm{~m}$; body mass: $74.2 \pm 9.7 \mathrm{~kg}$ ) were assigned to an experimental group $(n=17)$ that performed exercise intervention (i.e., aerobic-anaerobic exercise at moderate-intensity plus behavioural training), or a control group $(n=17)$. At baseline and after 8-week, COPE-NVI (60-item self-report questionnaire), CD-RISC (10-item scale) and physical fitness tests (i.e., Stork balance stand, functional reach, lateral sidestep and push-up tests) assessed coping skills, resilience and fitness levels, respectively. A 2-way analyses of variance (ANOVA) with repeated measures and paired t-test analysis were performed to locate between- and within-trial variance, and the magnitude of significant effects was determined using Cohen's $d$ effect sizes. Statistical significance level was set at $P<0.05$. Adherence to exercise was $94 \pm 2,6 \%$ and after intervention significant improvements in the skills and strategies adopted to cope with stressful events $(P<0.01, d=0.80)$ and in ability to deal with negative experiences $(P<0.01$, $d=0.87$ ) were found. In addition, the physical fitness components as static $(P<0.01, d=0.96)$ and dynamic balance $(P<0.01, d=0.75)$, anaerobic power and coordination $(P<0.01, d=0.89)$, and endurance of the upper body musculature $(P<0.01, d=0.58)$ are significantly improved in the experimental group. No relevant changes were found in the control group. Findings highlighted the positive relationship between increased physical fitness and improved functional and adaptive modalities used to cope with stressful events and negative experiences. Therefore, exercise intervention was effective to improve mental and physical wellbeing in drug addicts. 
Index

\section{Key to abstract codes}

Unique codes. Each abstract has an unique code to assist you in identifying whether the abstract is a poster or free communication presentation and in which session it will be presented.

Page numbers. For each abstract a page number is provided, giving the location of where it is published in this booklet.

Poster presentations. There are two poster presentation sessions:

1. Day 1

2. Day 2

Poster presentations have a code such as D2.P1.

Free communication presentations. There are 15 free communication presentation sessions: Free communication presentations have a code such as D1.S3.1(1).

\section{Index}

Acosta, Edgar, D1.P11, D2.P16, D2.S1.1(6)

Ahlebrand, August, D2.P6

Akubat, Ibraham, D1.S4.5(6)

Aldous, Jeffrey, D1.S4.2(6), D1.S4.4(1)

Allanson, Matthew, D1.S4.3(1)

Alway, Peter, D1.S4.5(1), D2.S1.2(3)

Anderson, Glenda, D2.P21

Andersson, Åsa, D2.P6

Andrew, Matthew, D2.S1.4(4)

Androulakis-Korakakis, Patroklos, D1.S4.5(2)

Archer, David, D1.S4.4(2)

Arede, Jorge, D1.P29, D2.S1.5(1)

Ariffin, Nur Haida, D2.S1.3(5)

Ashby, Jack, D2.P1

Ávila, Cristian, D1.P11, D2.P16, D2.S1.1(6)

Azeem, Muhammad, D2.P27

Bailey, Daniel, D1.S4.1(1), D1.S4.1(2), D1.S4.2(6), D2.S1.2(4)

Bain, Tanith, D1.P15

Baldock, Lee, D2.P23

Balshaw, Thomas, D2.S3.1(3)

Bannell, Daniel, D1.P16

Baross, Anthony, D1.S4.5(4)

Barquero Jiménez, José, D1.S4.5(5)

Barragán, Daniela, D1.P11, D2.P16, D2.S1.1(6)

Batey, Jo, D1.P22

Bauer, Alexander, D2.S3.4(1)

Beato, Marco, D2.S1.5(5)

Benítez-Porres, Javier, D1.P42

Bennett, Anthony, D2.S1.5(2)

Berger, Nicolas, D2.S1.2(5)

Biddulph, Brett, D1.P17

Bird, John, D1.P23

Bissas, Athanassios, D1.P3

Blagrove, Richard, D1.P37

Blažica, Bojan, D1.P1

Blundell, John, D1.S4.1(6)

Board, Elisabeth, D1.S4.4(2)

Boekschoten, Mark, D1.S4.2(3)

Bonilla, Diego, D1.P42

Bottaro, Martim, D1.P26

Bottoms, Lindsay, D2.S1.2(1)

Bourne, Nicholas, D2.P33
Boyd, Andy, D1.P15, D2.S3.5(4)

Bradley, Eddie, D1.S4.4(2)

Bradley, Scott, D2.P25

Brierley, Marsha, D1.S4.1(2)

Brock, Kirsty, D2.P17

Brogden, Chris, D1.P38

Brooke-Wavell, Katherine, D1.S4.1(5), D1.S4.5(1), D2.S1.2(3), D2.S3.1(3)

Brown, Hazel, D2.P15, D2.P17

Brown, James, D2.S1.1(2)

Brown, Natalie, D2.S1.3(1)

Brown, Peter, D1.S4.2(5)

Buckland, Nicola, D1.S4.1(6)

Budzynski-Seymour, Emily, D2.P9

Burgess, Darren, D2.P39

Burt, Dean, D1.P30

Buscombe, Richard, D2.P33

Cameron, Brian, D2.S3.3(1)

Campbell, Ian, D2.S1.2(1)

Campbell, Jennifer, D2.S3.2(4)

Carbone, Leandro, D1.P42

Cardozo, Luis, D1.P7

Carlin, Liz, D2.S1.3(2)

Carlson, Lara, D2.S1.4(7), D2.S3.3(1)

Carney, Daniel, D2.S1.2(2)

Carpentier, Julie, D2.P30

Carrillo, Cristian, D1.P11, D2.P16, D2.S1.1(6)

Castillo, Carlos, D1.P2, D2.P41

Castro, Nicolás, D1.P42

Cataldi, Stefania, D1.S4.1(4)

Caviativa, Yaneth Patricia, D2.S1.1(6), D1.P11, D2.P16

Celis-Morales, Carlos, D2.P10

Champion, Rachael, D1.S4.1(1)

Charnock, Lewis, D2.S3.3(5)

Chater, Angel, D1.S4.1(2)

Chulvi-Medrano, Iván, D1.P42

Church, Matthew, D1.P22

Clark, Dave R., D1.S4.4(3)

Clarke, Hannah, D1.P32

Clarkson, Beth, D2.P24

Cline, Alice, D1.P8

Close, Graeme, D2.S1.2(2)

Cole, Matthew, D1.P12

Collins, Kieran, D2.S3.5(1), D2.S3.5(3) 
Collins, Kieran, D1.P31

Comyns, Thomas, D1.P33

Comyns, Tom, D2.S1.5(3)

Connell, Louise, D1.P9

Cooper, Simon, D2.S1.5(2)

Coratella, Giuseppe, D2.S3.5(3)

Cotterill, Stewart, D2.P17, D2.P24, D2.S1.3(7)

Cousins, Ben, D2.S1.5(2)

Cowley, Emma, D2.P10

Cox, Ashley, D2.S3.2(1)

Cox, Val, D2.P11

Craig, Thomas, D2.S3.5(2)

Croft, Louise, D2.S1.2(4)

Cropley, Brendan, D1.S4.3(2), D2.P23

Cumming, Sean, D2.S1.5(1)

Curtis, Christopher, D1.P19

Dawes, Marisa, D2.S1.4(7), D2.S3.3(1)

Day, Adrienne, D1.P9

Day, Amy, D2.P29

De Filippo, Rebecca, D1.P8

De Silva, Luciana, D1.P8

Deb, Sanjoy K., D2.S3.3(2)

Dekkers, Thomas, D1.P31

Delahunt, Eamonn, D2.S3.1(4)

Di Terlizzi, Piergiorgio, D1.S4.1(4)

Dillern, Thomas, D1.P24

Dimitriou, Lygeri, D1.P19

Dobell, Alexandra, D2.P11

Dolby, Melissa, D1.P4

Dolenec, Aleš, D2.P7

Dougan, Kayleigh, D2.P25

Draper, Stephen, D1.P8, D2.S3.1(5)

Drury, Benjamin, D1.P32

Drust, Barry, D2.S1.4(2), D2.S1.4(4)

Duncan, Michael, D1.S4.1(3), D2.P11, D2.S1.1(5)

Dunlop, Mark, D2.P12

Edmonds, Ross, D2.P19

Elferink-Gemser, Marije, D2.P34

Ellert, Guido, D2.S3.4(1)

Elliott, Anne, D2.P13

Emmonds, Stacey, D1.P34, D2.S3.1(1)

English, Cedric, D2.S3.4(5)

Enright, Kevin, D2.S1.4(2)

Esperance, Oliva Rose, D2.P26

Evans, Andrew, D2.S3.4(3)

Evans, Vicki, D2.P20

Evans, Will, D1.S4.4(2)

Eyre, Emma, D1.S4.1(3), D2.P11

Faghy, Mark, D1.S4.2(5), D2.P11

Fairclough, Stuart, D2.S3.2(1), D2.S3.2(5)

Fälth, Jenny, D2.P6

Faulkner, Jade, D2.P4

Faulkner, James, D2.P15, D2.P17, D2.S1.1(1), D2.S1.2(7)

Felton, Malika, D2.P17

Fernandes, John, D1.P32

Ferreira, António, D1.P29

Filippits, Norbert, D2.S3.3(1)

Finlayson, Graham, D1.S4.1(6)

Firth, Joseph, D1.S4.3(6)

Fischetti, Francesco, D1.S4.1(4)
Fish, Michael, D2.S1.4(1), D2.S1.5(4)

Fisher, Abigail, D1.S4.3(6)

Fisher, James, D1.S4.5(2)

Fitzgerald, Shaun, D1.S4.5(3)

Folland, Jonathan, D1.S4.1(5), D2.S3.1(3)

Fong, Daniel, D2.S3.1(4)

Forrest, Laura, D2.S1.3(1)

Forsyth, Jacky, D1.P30

Fransen, Katrien, D2.P24

Fraser, Kotryna, D2.S3.3(1)

Free, Bonnie, D2.S1.2(6)

Fryer, Simon, D2.P17, D2.S1.1(1)

Fujihira, Kyoko, D1.P18

Galvis, Pedro, D1.P11, D2.P16, D2.S1.1(6)

Garcia, Carolina, D1.P11, D2.P16, D2.S1.1(6)

García, Luis, D1.P11, D2.P16, D2.S1.1(6)

Garcia-Aparicio, Amaia, D2.P14

Gentil, Paulo, D1.P26

Gibson, Kass, D1.S4.2(4)

Girling, William, D1.P19

Giske, Rune, D1.P24

Glass, Carol, D2.S1.3(7)

Gledhill, Adam, D1.S4.3(1), D2.S1.3(4), D2.S3.3(4)

Gorczynski, Paul, D1.S4.2(4)

Gough, Lewis A., D1.P38, D1.S4.2(1), D2.S3.3(2)

Gowing, Lucy, D1.P21

Graefe, Andreas, D2.S3.4(1)

Granados, Jaime, D1.P2

Gravestock, Helen, D1.P3

Gray, Stuart, D2.P10, D2.P22

Gray, Thomas, D2.P3

Greco, Gianpiero, D1.S4.1(4)

Green, Matt, D2.S1.4(4)

Griffin, Alan, D1.P33

Grimshaw, Paul, D1.S4.5(3)

Gudmundsdottir, Sigridur, D2.P31

Gurton, William, D1.S4.2(2)

Gustafsson, Henrik, D1.S4.3(5)

Gutiérrez, Catalina, D1.P2

Haglund, Emma, D2.P6

Haines, Matthew, D2.S1.4(1), D2.S1.5(4)

Hajar, Mawar, D2.S3.2(3)

Hamada, Yuka, D1.P18

Hangelbroek, Roland, D1.S4.2(3)

Haq, Adnan, D1.S4.5(4)

Harding, Jamie, D1.S4.4(5)

Harper, Damian, D2.S1.4(6)

Harrison, David, D1.S4.3(3)

Hartley, Chris, D1.S4.1(5)

Harwood, Chris, D1.S4.2(4)

Hassan, David, D2.S1.3(2)

Hawkey, Adam, D1.P4, D2.P3, D2.P4

Hayman, Oliver, D1.P30

Hegrestad, Camilla, D1.P24

Helme, Mark, D1.P34, D2.S3.1(1)

Heritage, Phill, D2.S1.1(7)

Heritage, Phillip, D2.P32

Hesford, Christian, D1.P35

Hettinga, Florentina, D2.P34

Hewson, David, D1.S4.1(1)

Hewson, Harriet, D1.P5 
Heywood, Abigail, D1.P36

Higgins, Matthew, D1.S4.2(1), D2.S3.3(2)

Hill, Andrew P., D1.S4.3(5)

Hill, Matt, D1.S4.1(3)

Hobbs, Helen, D2.S1.1(1)

Hoekstra, Sven, D1.P35

Holder, Tim, D2.S1.3(7)

Hopman, Maria, D1.S4.2(3)

Horgan, Barry, D2.S3.5(1)

Horner, Louisa, D2.S3.2(2)

Hough, John, D1.S4.4(1)

Howard, Luke, D1.S4.3(4)

Huijgen, Barbara, D2.P34

Humphrey, Jack, D2.S1.1(7)

Hunter, David, D2.P21

Huntley, Emma, D1.S4.3(2)

Hurst, Howard, D1.P9

Hurst, Philip, D2.S3.4(2)

Hussey, Beth, D2.P21

Iga, John, D2.S1.4(2)

Jackson, Daniel, D1.P37

Jackson, Sarah, D1.S4.3(6)

James, Lynsey, D2.P21

James, Rob, D2.S1.1(5)

Jiménez, Samuel, D1.P11, D2.P16, D2.S1.1(6)

Jobson, Simon, D2.S1.2(7)

Johnston, Lynsey, D2.P22

Johnstone, James, D1.S4.3(6)

Jones, Benjamin, D2.S1.4(3)

Jones, Helen, D1.P16

Jones, Leighton, D1.S4.3(4)

Jones, Michelle, D2.P9

Jones, Rebecca, D2.S1.2(4)

Jones, Victoria, D2.P5

Jukic, Ivan, D1.P40, D2.S1.5(6)

Karageorghis, Costas, D1.S4.3(4)

Kaufman, Keith, D2.S1.3(7)

Kavussanu, Maria, D2.S3.4(2)

Keane, John, D2.S3.5(3)

Keenan, James, D1.S4.2(5)

Kelly, Adam, D1.P12, D1.P37, D1.P38

Kelso, Richard, D1.S4.5(3)

Kenny, lan, D1.P33

Kerr Cumbo, Renzo, D2.S1.3(3)

Kerslake, Robert, D1.S4.1(5)

Keylock, Laura, D2.S1.2(3)

Khan, Mohammed Sayeed, D2.P27

Killey, Jenny, D2.S1.5(4)

King, Mark, D1.S4.5(1), D2.S1.2(3)

Kinnafick, Florence, D1.S4.2(4)

Kirk, Christopher, D1.S4.4(3)

Kirkland, Andrew, D2.S3.3(3)

Kite, Chris, D2.S1.1(2)

Kite, Rich, D2.P33

Klass, Malgorzata, D2.P30

Knight, Camilla, D2.S1.3(1)

Knowles, Zoe, D1.S4.3(2), D2.S1.4(4)

Knox, Gareth, D1.P8
Knuiman, Pim, D1.S4.2(3)

Konings, Marco, D2.P34

Kosciuk, Anna, D2.S3.1(2)

Kosteli, Maria-Christina, D2.S3.2(1)

Kuan, Garry, D1.P10, D2.S1.3(5), D2.S3.2(3)

Kueh, Yee-Cheng, D1.P10, D2.S1.3(5), D2.S3.2(3)

Kyrou, loannis, D2.S1.1(2)

Labrador, Sergio, D1.P7

Lacerda, Adriana, D2.P27

Lahart, Ian, D2.S1.1(2)

Lambert, Megan, D2.S1.3(4)

Lambrick, Danielle, D2.S1.1(1)

Langan-Evans, Carl, D1.S4.4(3)

Langley, Ben, D1.S4.5(1)

Lawson, Chelsey, D1.S4.1(3)

Leddington-Wright, Sheila, D1.S4.1(3)

Leicht, Christof, D1.P35

Leite, Nuno, D1.P29, D2.S1.5(1)

Lewis, Liane, D2.P12

Lewis, Martin, D1.P17, D2.P1

Lindley, Martin, D2.P21

Littlewood, Martin, D2.S1.2(2), D2.S3.3(5)

Logan, Oliver, D2.P5

Lóio, António, D1.P29

Lothian, Daniel, D2.S1.4(2)

Lovera, Cesar, D1.P7

Low, Chris, D1.P34, D2.S3.1(1)

Low, David, D1.P16

Lyons, Mark, D1.P33, D2.S1.5(3)

MacFarlane, Niall, D2.P22

MacPherson, Tom, D1.S4.4(4)

Madden, Jonathan, D1.P39

Maden-Wilkinson, Thomas, D2.S3.1(3)

Maden-Wilkinson, Tom, D1.S4.2(5)

Madigan, Daniel J., D1.S4.3(5)

Magee, Pamela, D1.P27

Malecek, Jan, D1.P40, D2.S1.5(6)

Maloney, Sean, D2.P7

Manley, Andrew, D1.S4.3(1)

Martin, Sarah, D2.P20, D2.P29

Martindale, Amanda, D2.P28

Martinelli, Louis, D2.S1.1(1)

Martins, João, D1.P29

Mastana, Sarabjit, D2.P21

Mataruna-Dos-Santos, Leonardo Jose, D2.P27

Mayes, J. P., D1.S4.2(5)

McCormack, Jacqueline, D1.P27

McDermott, Emmet, D2.S3.1(3)

McDonald, Peter, D1.S4.4(1)

McErlain-Naylor, Stuart, D2.S1.5(5)

McEwan, Hayley, D2.P28

McKnight, Peter, D2.S1.4(7)

McLaren, Shaun, D1.S4.4(4)

McNally, Steven, D1.P21

McNamara, Jack, D2.P13

McNaughton, Lars, D1.S4.2(1), D2.S3.3(2)

Mellalieu, Stephen, D2.P23

Mendes, André, D1.P29

Mensink, Marco, D1.S4.2(3) 
Menting, Stein, D2.P34

Menzies, Fraser, D2.S3.5(4)

Miles, Andy, D1.S4.3(2)

Milla, Asli Cazorla, D2.P27

Milligan, James, D2.S1.5(4)

Mills, John, D2.S1.4(3)

Mistry, Amit, D1.S4.3(6)

Mitchell, Andrew, D1.S4.2(6)

Mitchell, Tom, D2.S3.3(4)

Miyashita, Masashi, D1.P18

Moir, Hannah, D2.S3.1(2)

Montrezol, Fabio, D1.P16

Moore, Lee, D2.P38

Morales, Natalia, D1.P11, D2.P16, D2.S1.1(6)

Moral-Moreno, Luis, D2.P14, D2.S1.1(3)

Moran, Jason, D1.P32

Morari, Victoria, D2.S1.2(4)

Moreno, Leidy, D1.P11, D2.P16, D2.S1.1(6)

Morris, John, D1.P17, D2.P1, D2.S1.5(2)

Morris, Martyn, D1.S4.1(3)

Morris, Rob, D2.S3.3(5)

Morrison, Andrew, D1.P6

Morton, James P., D1.S4.4(3), D2.S1.4(2)

Mosscrop, Emma, D2.P5

Moulashis, Panayiotis, D1.S4.3(4)

Muhamad, Ayu, D2.S3.2(3)

Murphy, Rebecca, D2.S1.2(2)

Murray, Andrew, D1.P15

Myers, Anna, D1.S4.1(6)

Myers, Tony, D1.S4.5(6)

Nabergoj, Matija, D1.P1

Nankervis, Kathryn, D2.S3.1(5)

Naylor, Samuel, D2.P36

Naylor, Thomas, D2.P36

Neil, Greg, D2.S3.4(4)

Neil, Rich, D2.P23

Nesti, Mark, D2.S3.3(5)

Nevill, Alan, D2.S1.5(3)

Newton, Robert, D2.P39

Nicholas, Donna, D2.S1.1(4)

Noonan, Robert, D2.S3.2(1)

Ntasis, Lazaros, D1.P25

Nunes, Vitoria, D1.P26

O'Malley, Callum, D2.S3.4(3)

O'Sullivan, David, D2.S1.4(1)

Oates, Luke, D2.S1.2(1)

Olsson, M. Charlotte, D2.P6

Omcirk, Dan, D1.P40, D2.S1.5(6)

Page, Tom, D2.S1.4(4)

Paice, Katherine, D1.P19

Paine, Eloise, D2.P15, D2.S1.2(7)

Panagi, Thalia, D1.P25

Papathomas, Anthony, D1.S4.2(4)

Payton, Carl, D2.P5

Peirce, Nicholas, D1.S4.5(1), D2.S1.2(3)

Peña, Jhonatan, D1.P2, D1.P7, D2.P41

Penitente, Gabriella, D1.P5

Perdomo, Angela, D1.P7

Perry, Dave, D1.P21
Peterca, Jošt, D1.P19, D2.P7

Petro, Jorge, D1.P42

Phillips, Shaun, D2.P42, D2.S1.3(6), D2.S3.2(4)

Pico, Juan, D1.P11, D2.P16, D2.S1.1(6)

Pieles, Guido, D1.P21

Pineau, Tim, D2.S1.3(7)

Pitkethly, Amanda, D2.S3.4(5)

Podlogar, Tim, D2.S1.2(6)

Price, Michael, D2.S1.2(1)

Price, Mike, D2.S3.3(2)

Protheroe, Laurence, D2.S3.1(5)

Pujdak, Mikolaj, D1.P19

Raedeke, Thomas D., D1.S4.3(5)

Raffermati, Nicole, D1.S4.4(1)

Raizaday, Shobhit, D2.S1.4(5)

Ramírez, Cristian, D1.P11, D2.P16, D2.S1.1(6)

Ramirez-Campillo, Rodrigo, D1.P26

Randeva, Harpal, D2.S1.1(2)

Range, Daniel, D2.P27

Reed, Katharine, D1.S4.2(2)

Relf, Tom, D1.P5

Ribbans, William, D1.S4.5(4)

Richards, Hugh, D2.S1.3(6)

Richards, James, D1.P9

Richards, Joanna, D1.S4.2(6), D1.S4.4(1)

Richardson, Cassandra, D2.S3.2(5)

Rimmer, Steven, D1.S4.2(1)

Rincón, Frank, D1.P7

Ring, Christoper, D2.S3.4(2)

Riveros, Manuel, D1.P11, D2.P16, D2.S1.1(6)

Rizal, Hussein, D2.S3.2(3)

Roberts, Ross, D2.S3.4(5)

Roberts, Simon, D2.P38, D2.S1.4(2)

Roberts, Spencer, D2.S3.5(5)

Rodriguez, Jaime, D1.P11, D2.P16, D2.S1.1(6)

Rogers, Kate, D2.S1.1(7)

Roscoe, Clare, D2.P11, D2.S1.1(5)

Rowat, Owain, D2.S1.4(6)

Rowlands, Alex, D1.S4.1(3)

Rubiano, Oscar, D1.P11, D2.P16, D2.S1.1(6)

Ryan, Aaron, D1.P41, D1.P43

Ryan-Stewart, Helen, D2.S1.2(7)

Ryder, Emily, D2.S1.1(4)

Ryding, Diane, D1.P21

Sabo, Abdulwali, D1.P10

Safi, Ayazullah, D1.P12

Salazar Rojas, Walter, D1.S4.5(5)

Sale, Craig, D2.S3.3(2)

Sánchez, Isabel, D1.P11, D2.P16, D2.S1.1(6)

Sanchis-Sanchis, Roberto, D2.P1

Sandercock, Gavin, D2.S1.4(3)

Sands, William, D1.P5

Sant'anna, Ricardo, D2.P38

Santich, Sam, D1.S4.3(4)

Santos, Wanderson Divino Dos, D1.P26

Sarkar, Mustafa, D1.S4.3(3)

Saward, Chris, D1.S4.3(3)

Sayegh, Suzan, D1.S4.1(1)

Scobie, Nairn, D2.S1.4(5)

Shahtahmassebi, Golnaz, D2.S1.5(2) 
Shalfawi, Shaher, D1.P24, D2.S1.5(7)

Simpson, Ellen, D1.P27

Smith, Alan L., D1.S4.3(5)

Smith, Lee, D1.S4.3(6)

Smith, Lindsey, D1.S4.1(2)

Smith, Michelle, D2.P28

Smith, Phillip, D2.S1.2(5)

Sotheran, Adam, D1.P5

Sparks, Andy, D1.S4.2(1), D2.S3.3(2)

Spears, lain, D1.S4.4(4)

Speirs, Derrick, D2.S3.5(4)

Spencer, Amy, D2.S1.3(7)

Springham, Matthew, D2.P39

Sproule, John, D2.P42

Steele, James, D1.P26, D1.S4.5(2), D2.P9

Stokes, Keith, D2.P38

Stone, Keeron, D2.P17, D2.S1.1(1)

Stoner, Lee, D2.P15, D2.S1.1(1)

Strigas, Ethan, D1.P25

Strongman, Clare, D1.P6

Stuart, A. Graham, D1.P21

Stubbs, Brendon, D1.S4.3(6)

Sunderland, Caroline, D1.P17, D1.S4.3(3), D2.P1, D2.S1.5(2)

Suzuki, Katsuhiko, D1.P18

Swann, Nicola, D2.S3.1(2)

Sweeney, Liam, D1.S4.4(1)

Swinton, Paul, D2.S3.5(2)

Szedlak, Christoph, D1.P22

Tallis, Jason, D1.S4.1(3)

Tasker, Edward, D2.S1.2(7)

Taylor, Alyx, D2.S1.1(7)

Taylor, Ian, D1.P23

Taylor, Jonathan, D1.S4.4(4)

Taylor, Richard, D1.S4.5(6)

Tellez, Luis, D2.P41

Teo, Wei-Peng, D2.S3.5(5)

Thain, Peter, D1.P37

Thelwell, Richard, D1.S4.2(4)

Thijssen, Dick, D1.P16

Thomas, Rhys, D1.S4.3(4)

Tiernan, Caoimhe, D2.S1.5(3)

Till, Kevin, D1.P34, D2.S3.3(4)

Tod, David, D2.P28

Tooley, Ed, D1.P15

Trott, Mike, D1.S4.3(6)

Tucker, Catherine B., D1.P3

Tufano, James, D1.P40, D2.S1.5(6)

Turner, Anthony, D1.P15, D2.P42, D2.S1.4(7), D2.S3.5(4)

Turner, Elliot, D1.P37
Turner, Tony, D2.S3.3(1)

Tyler, Christopher, D1.S4.4(1)

Tyler, Richard, D2.S3.2(5)

Valencia, Edwin, D1.P11, D2.P16, D2.S1.1(6)

Van Loon, Luc, D1.S4.2(3)

Van Wyk, Alechia, D1.P19

Vargas, Juan, D1.P11, D2.P16, D2.S1.1(6)

Vargas, Salvador, D1.P42

Vidal, Marina, D1.P19

Vieira, Carlos, D1.P26

Vučković, Goran, D2.P7

Waldron, Mark, D1.S4.4(5), D2.P39

Walker, Natalie, D1.P12

Wallace, Kyle, D1.P27

Wallis, Gareth, D2.S1.2(6)

Wang, Dan, D2.S3.1(4)

Warmington, Stuart, D2.S3.5(5)

Warr, Andrew, D1.S4.5(3)

Warrington, Giles, D2.S1.5(3)

Wass, Joshua, D1.S4.4(6)

Watkins, Philip, D2.P8

Watson, Madeleine, D1.P28

Webb, Rachel, D2.S1.3(6)

Weston, Matthew, D1.S4.4(4)

Wilkins, Celeste, D2.S3.1(5)

Williams, Craig, D1.P21

Williams, Emily, D1.P36

Williams, Graham, D1.P41, D1.P43

Williams, John, D2.P26

Wimshurst, Zoe, D2.S3.4(4)

Witkamp, Renger, D1.S4.2(3)

Wouters, Jeroen, D1.S4.2(3)

Wright, Amy, D2.S1.1(1)

Wu, Yunchuan, D2.S3.1(4)

Xu, Yilin, D2.S3.1(4)

Yánez, Cristian, D1.P2, D1.P7, D2.P41

Yang, Weiwei, D2.S3.1(4)

Yates, James, D1.S4.2(6)

Young, Damien, D2.S3.5(3)

Yuan, Peng, D2.S3.1(4)

Zakrzewski-Fruer, Julia, D2.S1.2(4)

Zamora, Paula, D1.P11, D2.P16, D2.S1.1(6)

Zhang, Shuge, D2.S3.4(5)

Zhao, Xiang, D2.P42 